\title{
Effect of Parental Deprivation on Self Confidence of Adolescents
}

\author{
Renu Tomer*, Dr. Alpna Agrawal**
}

\section{ABSTRACT:}

The aim of this study was to explore the effect of parental deprivation on self-confidence of adolescents. In the present study $4 \times 2$ factorial design was used. There were two independent variables, the first independent variable was parental deprivation, and distinguished at four levels that is mother deprivation, father deprivation, both deprivation and no deprivation. The second independent variable was gender distinguished at two levels that is male and female. 160 subjects (9th and 10th class) were selected for the study. Out of which 40 subjects have mother deprivation, 40 have father deprivation, 40 have both deprivation and 40 have no deprivation. In each group there were equal no of male and female. Data was collected with the help of "Agnihotri self-confidence Inventory". Obtained data were analyzed by mean, ANOVA and newman-Keuls comparison test, result reveal that parental deprivation and gender significantly affect the self-confidence of adolescents.

Keywords: Self Confidence, Parental Deprivation

\section{INTRODUCTION}

Self-confidence is essentially an attitude which allows us to have a positive and realistic perception of ourselves and our abilities. It is characterized by personal attributes such as assertiveness, optimism, affection, pride, independence, trust, the ability of handle criticism and Emotional maturity. Confidence is learned, it is not inherited. (Sears, Albert 1990). Ceibb (2003) told that "Self-confidence is the result of a successfully survived risk". Cox, (2001) told that "Self-confidence is a belief in yourself and or abilities, a mental attitude of transiting or relying on yourself".

The role of parents in instilling self-confidence in their children is very important. Parents who always criticize their children without acknowledging the latter strengths unknowingly dampen the development of their self-confidence, on the other hand, parents who are always willing to give support encourage their children to take a step forward will most likely rear self-confident children. Parents who make their children feel loved and accepted despite their imperfection will most likely encourage self-confidence. Toddlers (1990) found that when parents have high expectation, he may develop low self-confidence by the way they respond to his behaviour and choices.

*Clinical Psychologist, M.A, M.Phil, ADACP, PGDBA,Ph.D., Dept. Of Psychology, Meerut College, Meerut. \& **Dept. Of Psychology, Meerut College, Meerut.

(C) 2014 R Tomer, A Agrawal; licensee IJIP. This is an Open Access Research distributed under the terms of the Creative Commons Attribution License (http://creativecommons.org/licenses/by/2.0), which permits unrestricted use, distribution, and reproduction in any Medium, provided the original work is properly cited. 
Overly strict or judgment responses can create negative effect on the self-confidence of children. The children who have low self-confidence in one or more areas do not believe that they can succeed in those areas. Worden and Silverman (1996) did a study on community-based sample of parentally bereaved children and composed their response to those from unattached non bereaved controls. The bereaved showed higher levels of social with-drawl, anxiety and social problems as well as lower self-confidence and self-efficacy.

In general terms self-confidence believes in you. Believing that you have what it takes to accomplish whatever you set your mind to.

\section{METHOD}

Purpose: The purpose of the present study was to study the effect of parental deprivation on self-confidence of adolescents.

\section{Hypothesis:}

1. There will be significant effect of parental deprivation on self-confidence of adolescents.

2. There will be significant effect of gender on self-confidence of adolescents.

3. There will be significant interaction effect between parental deprivation and gender on self-confidence.

\section{Design}

In the present study $4 \times 2$ factorial design was used to complete the research work. In this study there were two independent variables, the first independent variable was parental deprivation distinguished at four levels that is mother deprivation, father deprivation, both deprivation and no deprivation. The second independent variable was gender distinguished at two levels that is male and female.

\section{Sample:}

160 subjects $\left(9^{\text {th }}\right.$ and $10^{\text {th }}$ class) were selected for the study. Out of which 40 subjects have mother deprivation, 40 have father deprivation, 40 have both deprivation and 40 have no deprivation. In each group there were equal no of male and female.

\section{Tool:}

For the measurement of self-confidence scale constructed by "Dr. Rekha Agnihotry" 1987 was used. This scale was been prepare with 56 items. The reliability coefficient obtained by test retest and split half method. The validity coefficient obtained is .82 which is significant beyond .01 level.

\section{Procedure:}

To measure self-confidence the ASCI scale was used. After establishing good rapport with subject the ASCI scale was distributed to subjects individually. The instructions of ASCI were written in the sample form of Hindi and in the clear sense. The subjects were requested to clear 
their doubts, if any. After this the inventories were taken back from all the subjects. In the end, thanks were paid to all subjects for providing their valuable time.

\section{RESULTS:}

Obtained data were analyzed with the help of mean, ANOVA and Newman-Keuls comparison test.

Summary table of ANOVA is shown in table No-1

Summary Table of ANOVA for Self-confidence Scores:

TABLE-1

\begin{tabular}{|l|c|c|c|c|}
\hline \multicolumn{1}{|c|}{$\begin{array}{c}\text { Source of } \\
\text { Variation 1 }\end{array}$} & SS' $^{\prime}$ & $\mathbf{d f}^{\prime}$ & MS & f-ratio \\
\hline $\begin{array}{l}\text { A(Parental } \\
\text { Deprivation) }\end{array}$ & 10576.87 & 3 & 3525.62 & $331.67^{* *}$ \\
\hline B (Gender) & 122.49 & 1 & 122.49 & $11.52^{* *}$ \\
\hline AxB & 302.51 & 3 & 100.84 & $9.48^{*}$ \\
\hline $\begin{array}{l}\text { With in group } \\
\text { (Error) }\end{array}$ & 1615.5 & 152 & 10.63 & - \\
\hline Total & 12617.37 & 159 & - & - \\
\hline
\end{tabular}

ANOVA table indicates that F-ratio for factor A (Parental Deprivation) is 331.67 which is greater than the critical value (3.91) at 0.01 level. It suggests that parental deprivation have significant effect on self-confidence of adolescents. The second main effect of gender as an independent variable represents a comparison of the levels of self-confidence between male and females. It is evident from the ANOVA table that F-value for factor B (Gender) is 11.52 which is greater than the critical value (6.81) at 0.01 level. It suggests that self-confidence also varies according to gender. ANOVA table indicates that the F-ratio of AxB is 9.48 which is greater than the critical value (3.91) at 0.01 level. This significant interaction between parental deprivation and gender shows that these two variables are dependent on each other. Mean scores selfconfidence for factor A and B are shown in Table-2. 
Table-2

\begin{tabular}{|l|c|}
\hline \multicolumn{1}{|c|}{ Group } & Mean Scores \\
\hline $\mathrm{a}_{1}$ (mother deprivation) & 17.75 \\
\hline $\mathrm{a}_{2}$ (Father Deprivation) & 17.5 \\
\hline $\mathrm{a}_{3}$ (both Deprivation) & 34.75 \\
\hline $\mathrm{a}_{4}$ (No Deprivation) & 13.75 \\
\hline $\mathrm{b}_{1}$ (Male) & 20.06 \\
\hline $\mathrm{b}_{2}$ (Female) & 21.81 \\
\hline
\end{tabular}

Table -2 indicate that $\mathrm{a}_{4}$ shows the lowest self-confidence scores, while $\mathrm{a}_{3}$ shows the highest selfconfidence scores. This quite clearly reveals that the subjects who have no deprivation of mother and father have the highest self-confidence while the subjects who have the deprivation of both mother and father have the lowest self-confidence. Male shows lower scores on self-confidence as compared to females. It signifies that males have high self-confidence than females

\section{DISCUSSION AND CONCLUSION:}

The purpose of the present study was to study the effect of parental deprivation and gender on self-confidence of adolescents. The first independent variable for this study was parental deprivation which was designated as 'A'. The significant F-ratio indicate that parental deprivation significantly affects the levels of self-confidence. Thus, the hypothesis that there will be significant effect of parental deprivation on self-confidence of adolescents is accepted. Laslett (1996) insist that parental loss has significant effect on the development of personality \& selfconfidence. It is the main factor of self-confidence of Individuals life. Beals \& Chaman (1991) found that the subjects who have parental loss during childhood are more depressed, feel less satisfied, lack of self-confidence with life, struggle with relationship and have poorer physical health.

The second independent variable for this study was gender varied in two ways by using male and female. F-ratio is significant for factor B at .01 level of confidence. Brown and Renz (2003) found that gender significantly affects the self-confidence. It signifies that male have high selfconfidence than female. Malanie (1996) insist that male have high self-confidence because they are more confident about their abilities to cope with problems and taken on new challenges.

In conclusion it can be said that parental deprivation significantly affects the self-confidence of adolescents. The subjects who have no deprivation of mother and father have the highest selfconfidence while the subjects who have the deprivation of both mother \& father have the lowest self-confidence. Males have high self-confidence than female. 


\section{REFERENCES:}

1. Basavana, M. (1975). Manual for self-confidence inventory Rupa Psychological Centre, Varanasi.

2. Ceibb, J. (2003). Self-concept of children and their intelligence achievement interest and anxiety. Retrieved May 11, 2011 http://www.kon.org.

3. Cox, R. (2001). Self-Concept of children and their intelligence achievement interests and anxiety. Retrieved May, 11, 2011 http://www.kon.org.

4. Farouk, M. (2009) Children, Concept of male \& female roles. Retrieved May 10, 2011 http://www.apa.org.

5. Laslett, P. (1996). Advance in early education \& day care. Retrieved may 10, 2001 http://www.b apa.org.

6. Sears and Albert (1990) The Social influence of confidence in group decision making. Retrieved May 10, 2011 http://www.apa.org.

7. Toddlers, A. (1990). Parental Death and Adjustment Retrieved May 12, 2011 http://www.apa.org

8. Warden W. Silverman, R. (1996). Parental Death and the Adjustment of school-Age children, Retrieved May, 12, 2011 from http://www.apa.org 